\title{
Mitotic Arrest and ChromosomerDoubling Using Thiabendazole, Cambendazole, Nocodazole and Ben Late in the Slime Mould Dictyostelium discoideum
}

\author{
By D. L. WELKER AND K. L. WILLIAMS* \\ Genetics Department, Research School of Biological Sciences, Australian National University, \\ P.O. Box 475, Canberra City, A.C.T. 2601, Australia
}

(Received 21 March 1979)

\begin{abstract}
Thiabendazole and cambendazole induced mitotic arrest and isogenic diploid formation through chromosome doubling in amoebae of the cellular slime mould Dictyostelium discoideum grown either axenically or in a bacterial suspension. The effect of nocodazole on axenically grown cells was similar to that of thiabendazole and cambendazole, but with cells grown on bacteria nocodazole was a much less effective inducer of mitotic arrest and did not lead to isogenic diploid formation. Benomyl, the active ingredient of ben late, had little or no effect on the induction of mitotic arrest and was a poor inducer of isogenic diploids in cells grown either axenically or on bacteria. All four benzimidazole derivatives were effective in haploidizing pre-existing diploids.
\end{abstract}

\section{INTRODUCTION}

Several studies have recently been aimed at determination of the karyotype of the cellular slime mould Dictyostelium discoideum (Robson \& Williams, 1977; Zada-Hames, 1977; Brody \& Williams, 1974; Sussman, 1961). These investigations have been hampered, however, by the inability to obtain large numbers of cells in metaphase. While the number of cells in metaphase can be increased by treatment with colchicine at high concentrations (Zada-Hames, 1977) or by release from starvation (Robson \& Williams, 1977), these techniques have not greatly facilitated routine chromosomal studies particularly with cells growing on bacteria.

In an attempt to find a simple and inexpensive method of obtaining large numbers of mitotically arrested cells and of producing isogenic diploids through chromosome doubling, we have investigated the effects of several benzimidazole derivatives on $D$. discoideum. Benzimidazole derivatives, in particular methyl benzimidazol-2-yl-carbamate (MBC) which is a decomposition product of benomyl (Clemons \& Sisler, 1969), have antimitotic activity in fungi such as Aspergillus nidulans and Ustilago maydis (Davidse, 1973; Davidse, 1975; Davidse \& Flach, 1977; Hammerschlag \& Sisler, 1973), in mammalian cells (Styles \& Garner, 1974; Seiler, 1975) and in higher plants (Zutshi \& Kaul, 1975). Benzimidazoles have been widely used as fungicides (benomyl, thiabendazole, cambendazole), as anthelminthics (thiabendazole) and as antitumour drugs (nocodazole, also called oncodazole). Structural formulae of the compounds used in this investigation are presented in Fig. 1.

We report the effect of the benzimidazole derivatives benomyl, cambendazole, nocodazole and thiabendazole on the induction of metaphase arrest and isogenic diploid formation in $D$. discoideum. While this work was in progress, the use of nocodazole as a mitotic inhibitor in $D$. discoideum was described by Cappuccinelli et al. (1979). 
Thiabendazole<smiles>c1ccc2[nH]c(-c3cscn3)nc2c1</smiles>

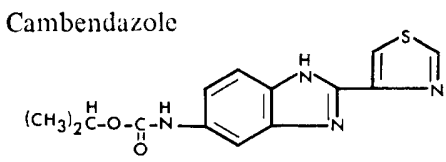

Nocodazole<smiles>COC(=O)Nc1nc2cc(-c3cccs3)ccc2[nH]1</smiles>

Benomyl<smiles>CNC(=O)n1c(NC(=O)OC)nc2ccccc21</smiles>

Carbendazim (MBC)<smiles>COC(=O)Nc1nc2ccccc2[nH]1</smiles>

Fig. 1. The structural formulae of benzimidazole derivatives.

\section{METHODS}

Culture of amoebae of D. discoideum. The haploid strain AX3 (Loomis, 1971) was used in all experiments in which the effect of the benzimidazole derivatives on the induction of mitotic arrest and isogenic diploid formation was investigated.'Strain DU319 (Williams \& Barrand, 1978) was used to determine the effects of the benzimidazole derivatives on haploidization of pre-existing diploids. Stocks of these strains were maintained on SM agar (Sussman, 1966) in association with a cobalt-resistant strain of Klebsiella aerogenes at $21 \pm 1{ }^{\circ} \mathrm{C}$ (Williams \& Newell, 1976). Amoebae were grown axenically in $25 \mathrm{ml}$ of the medium of Watts \& Ashworth (1970) in $125 \mathrm{ml}$ flasks on an orbital shaker $\left(150\right.$ cycles $\left.\mathrm{min}^{-1}\right)$ at $21 \pm 1{ }^{\circ} \mathrm{C}$. Exponentially growing amoebae were diluted to approximately $10^{6}$ amoebae $\mathrm{ml}^{-1}$ with fresh axenic medium for these experiments. For experiments with bacterially grown amoebae, the cultures were grown overnight to between $3 \times 10^{6}$ and $4 \times 10^{6}$ amoebae $\mathrm{ml}^{-1}$ in suspension with Escherichia coli $\mathrm{B} / \mathrm{r}$ (about $10^{9}$ bacteria $\mathrm{ml}^{-1}$ ) in phosphate buffered saline (Deering et al., 1970) and then diluted to $10^{6}$ amoebae $\mathrm{ml}^{-1}$ with fresh $E$. coli suspension. The bacterial suspensions $\left(5\right.$ to $20 \mathrm{ml}$ ) were rotated at 150 cycles $\min ^{-1}$ in $125 \mathrm{ml}$ flasks at $21 \pm 1{ }^{\circ} \mathrm{C}$. In some experiments amoebae were grown on suspensions of autoclaved $E$. coli (with $250 \mu \mathrm{g}$ dihydrostreptomycin sulphate $\mathrm{ml}^{-1}$ ) either with or without the addition of $10 \%(\mathrm{v} / \mathrm{v})$ of a filter-sterilized solution of Oxoid yeast extract $\left(70 \mathrm{~g} \mathrm{l}^{-1}\right)$ and Oxoid bacteriological peptone $\left(140 \mathrm{~g}^{-1}\right)$.

Chemicals. Ben late, a mixture of 50\% benomyl and $50 \%$ kaolinite, was obtained from DuPont (Australia) Ltd, North Sydney, N.S.W., Australia. Cambendazole and thiabendazole (both $97 \%$ pure) were the gift of William Bliss of Merck, Sharp \& Dohme Research Labs, Ingleburn, N.S.W., Australia. Nocodazole was obtained from Aldrich Chemical Co., Milwaukee, Wisconsin, U.S.A. Stock solutions were prepared in dimethyl sulphoxide (DMSO; Sigma grade 1) and kept frozen at $-10^{\circ} \mathrm{C}$ until use (ben late, $50 \mathrm{mg} \mathrm{ml}^{-1}$; cambendazole, $50 \mathrm{mg} \mathrm{ml}^{-1}$; thiabendazole, $10 \mathrm{mg} \mathrm{ml}^{-1}$; nocodazole, $5 \mathrm{mg} \mathrm{ml}^{-1}$ ). In early experiments, fresh aqueous suspensions of ben late were used; the results obtained, although consistent with those reported here, were more variable presumably due to inadequate dispersal of the ben late.

Cytological examination. Amoebae were fixed in methanol/acetic acid $(3: 1, \mathrm{v} / \mathrm{v})$ and air-dried on to slides as described previously (Brody \& Williams, 1974). The cells were either stained for 15 min with $10 \%$ (v/v) Gurr's Giemsa stain (Improved R66) in 0.07 M-Sorensen's phosphate pH 6.8, or, in most cases, treated with $0.25 \%(\mathrm{w} / \mathrm{v})$ trypsin (Difco, 1:250) in $0.85 \%(\mathrm{w} / \mathrm{v}) \mathrm{NaCl}$ for $90 \mathrm{~s}$ and then stained with Giemsa stain for $30 \mathrm{~min}$. The trypsin treatment was included to reduce cytoplasmic staining so that interphase nuclei could be 


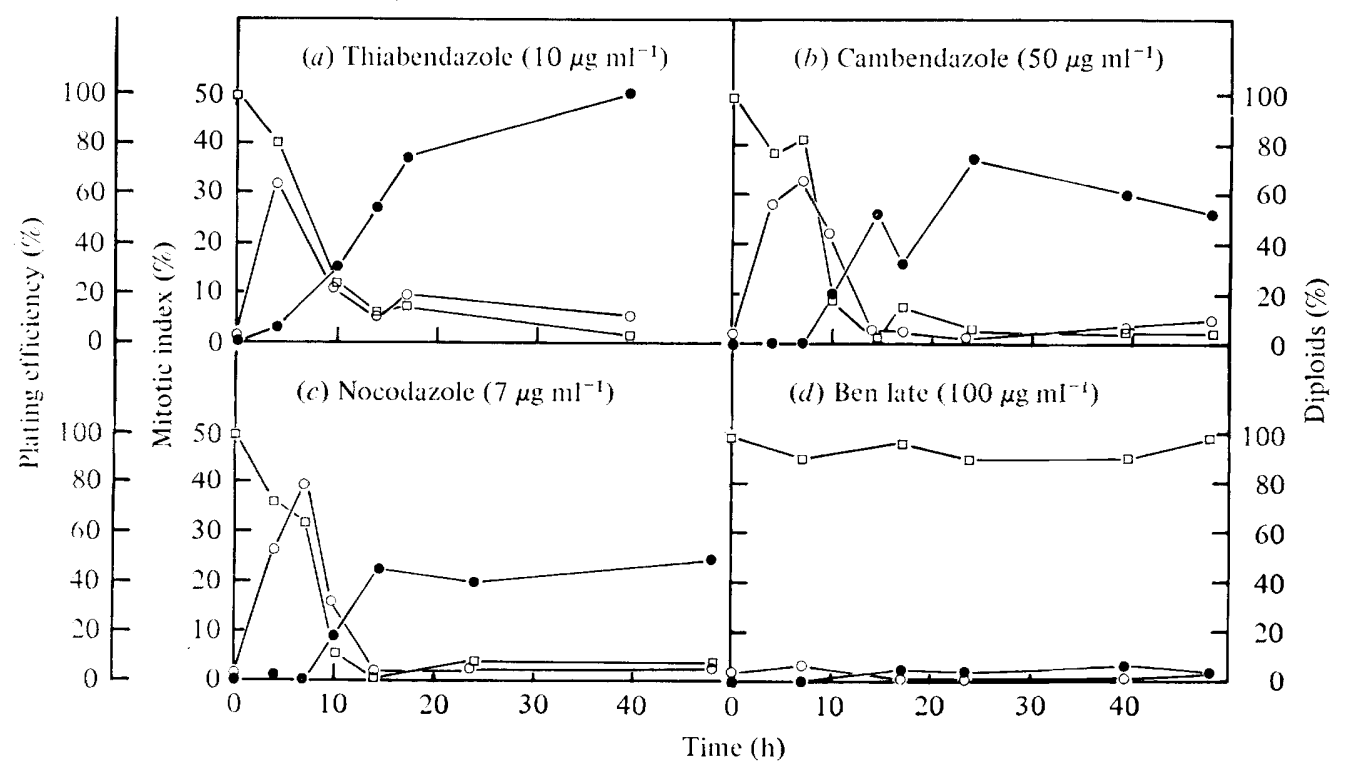

Fig. 2. The mitotic index (O), percentage of diploid colonies (O) and plating efficiency ( $\square$ ) of axenically grown amoebae of strain AX3 treated with thiabendazole $(a)$, cambendazole $(b)$, nocodazole $(c)$ or ben late $(d)$.

easily observed by light microscopy (Robson \& Williams, 1977). The mitotic index was determined by examining all nuclei in a series of randomly chosen fields; at least 1000 nuclei were examined for each sample.

Photography. Either Kodak Panatomic X or Copex Pan rapid film was used (Galeotti \& Williams, 1978).

Haploidization. Amoebae of diploid strain DU319 were plated clonally on to media containing the appropriate inhibitor. Agar containing ben late was prepared by adding a concentrated aqueous suspension of ben late to SM agar after autoclaving and cooling to $60^{\circ} \mathrm{C}$ (Williams \& Barrand, 1978). Agars containing cambendazole, nocodazole and thiabendazole were prepared by adding appropriate volumes of inhibitor/ DMSO stock solutions to SM agar after autoclaving and cooling to $60^{\circ} \mathrm{C}$. The concentration of DMSO in these plates was less than $0 \cdot 1 \%(\mathrm{v} / \mathrm{v})$ at the time of inoculation.

Determination of plating efficiency. Cell viability was measured by determining the ability of the amoebae to divide and form visible colonies in bacterial lawns on the surface of SM agar plates. Samples of the cell suspensions were removed after treatment with inhibitor for various times and diluted so as to obtain about 50 colonies per plate.

Determination of ploidy. Ploidy was routinely determined by examination of the size and shape of spores taken from individual colonies obtained in plating efficiency experiments. Spores were removed from fruiting bodies with sterile toothpicks, suspended in distilled water or Bonner's salt solution in 60-well Falcon 3034 microtest tissue culture plates and then examined using an Olympus $\mathrm{BH}$ microscope at $400 \times$ magnification. In some cases, ploidy was confirmed by cytological examination of chromosomes using either axenically or bacterially grown cells. For rapid cytological examinations, amoebae were removed from theedge of colonies growing on SM agar, suspended with $E$, coli $\mathrm{B} / \mathrm{r}$, treated with thiabendazole $\left(10 \mu \mathrm{g} \mathrm{ml}^{-1}\right)$ for $2.5 \mathrm{~h}$ at $21^{\circ} \mathrm{C}$ with shaking at 150 cycles $\mathrm{min}^{-1}$, fixed and then stained as described above.

\section{RESULTS}

\section{Effects of benzimidazole derivatives on axenically grown amoebae}

The mitotic index of axenically growing cells of AX3 increased from $1.9 \%$ to between 30 and $40 \%$ within 5 to $7 \mathrm{~h}$ exposure to thiabendazole $\left(10 \mu \mathrm{g} \mathrm{ml}^{-1}\right)$, cambendazole $(50 \mu \mathrm{g}$ $\mathrm{ml}^{-1}$ ) or nocodazole $\left(7 \mu \mathrm{g} \mathrm{ml}^{-1}\right)$ and then decreased to between 1 and $10 \%$ by $15 \mathrm{~h}$ (Fig. $2 a$, $b, c)$. Ben late $\left(100 \mu \mathrm{g} \mathrm{ml}^{-1}\right)$ had little effect on the mitotic index (Fig. $2 d$ ), since the maximum mitotic index obtained for ben late-treated cells was $3.3 \%(7 \mathrm{~h})$. Controls with or without DMSO, used at the concentration added with inhibitors $(0 \cdot 1 \%, v / v)$, gave the same mitotic index (1.9\%, mean of five experiments). 


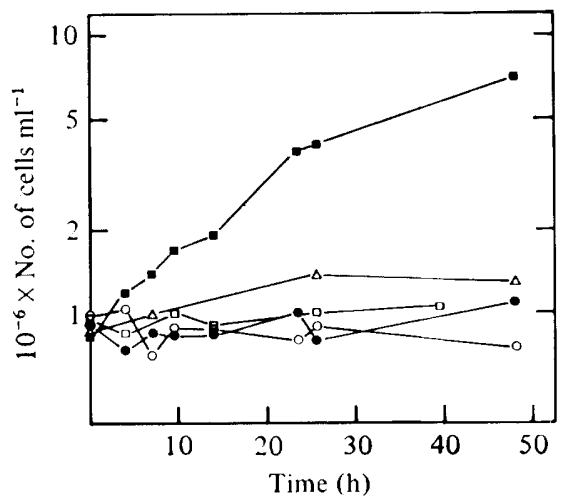

Fig. 3. Growth of amoebae of strain AX3 in axenic medium with no inhibitor $(\square), 10 \mu \mathrm{g}$ thiabendazole $\mathrm{ml}^{-1}(\square), 7 \mu \mathrm{g}$ nocodazole $\mathrm{ml}^{-1}(\mathrm{O}), 50 \mu \mathrm{g}$ cambendazole $\mathrm{ml}^{-1}(\bigcirc)$ or $100 \mu \mathrm{g}$ ben late $\mathrm{ml}^{-1}$ $(\triangle)$.

Table 1. Haploid, aneuploid and diploid mitotic figures in axenic cultures of strain AX3 treated with thiabendazole $\left(10 \mu \mathrm{g} \mathrm{ml}^{-1}\right)$

Subdivision of the mitoses scored in Fig. 2(a) into haploids $(n=7)$, aneuploids (8 to 13 chromosomes) and diploids $(2 n=14)$.

Percentage of mitotic nuclei

$\begin{array}{cccc}\text { Time (h) } & \text { Haploid } & \text { Aneuploid } & \text { Diploid } \\ 0 & 100 & 0 & 0 \\ 4 \cdot 0 & 100 & 0 & 0 \\ 9 \cdot 5 & 87 & 9 & 4 \\ 14 \cdot 0 & 41 & 39 & 20 \\ 17 \cdot 0 & 28 & 42 & 30 \\ 39 \cdot 5 & 16 & 44 & 40^{*}\end{array}$

* Includes two possible triploids out of 22 diploids seen.

A decrease in viability (as measured by plating efficiency) and an increase in isogenic diploid formation (Fig. $2 a, b, c$ ) coincided with the decrease in the mitotic index of thiabendazole-, cambendazole- or nocodazole-treated cells. The plating efficiency of these cells decreased to between 2 and $15 \%$ by $15 \mathrm{~h}$. The plating efficiency of ben late-treated cells did not decrease for at least $50 \mathrm{~h}$ (Fig. $2 d$ ). After $7 \mathrm{~h}$ the proportion of surviving cells giving rise to diploid colonies increased and reached a plateau of greater than $40 \%$ for thiabendazole-, cambendazole- and nocodazole-treated cells (Fig. $2 a, b, c$ ). With ben late, the percentage of diploids reached a plateau at about $5 \%$ (Fig. $2 d$ ). Diploids were observed among colonies obtained from the untreated control cultures at a frequency of less than $0 \cdot 1 \%$ ( 2 of 3400 colonies scored). At the concentrations used in the above experiments, cell division was blocked with thiabendazole, cambendazole and nocodazole and on average less than one round of cell division occurred following exposure to ben late (Fig. 3). At lower concentrations of the inhibitors the effects on growth arrest, mitotic index, plating efficiency and chromosome doubling were less marked. For example, with thiabendazole at $1 \mu \mathrm{g} \mathrm{ml}^{-1}$, the growth rate was similar to that of control cultures and the mitotic index was slightly increased $(4.2 \%, 7.25 \mathrm{~h})$ but isogenic diploids were not formed nor was the plating efficiency lowered. Following exposure to thiabendazole at $5 \mu \mathrm{g} \mathrm{ml}^{-1}$, only one round of cell division occurred and the mitotic index increased to $21 \%$ at $7.25 \mathrm{~h}$; however, after $48 \mathrm{~h}$ the plating efficiency remained above $20 \%$ and only $4 \%$ of colonies were diploid.

The appearance of aneuploid nuclei increased with time in cultures treated with thiaben- 


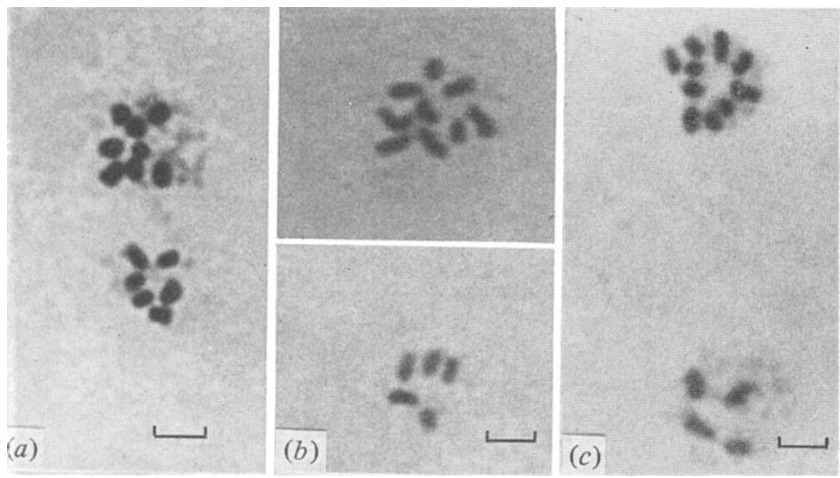

Fig. 4. Aneuploid mitoses showing (a) $6+8$ chromosomes, (b) $9+5$ chromosomes and (c) $10+4$ chromosomes. The mitotic nuclei were separated by $2.5 \mu \mathrm{m}$ in $(a), 56 \mu \mathrm{m}$ in $(b)$ and $10 \mu \mathrm{m}$ in $(c)$. These were found in axenic cultures of strain AX3 treated with $10 \mu \mathrm{g}$ thiabendazole $\mathrm{ml}^{-1}$ for $17 \mathrm{~h}$. Bar markers represent $2 \mu \mathrm{m}$.

dazole (Table 1), cambendazole or nocodazole. Initially, all mitoses were haploid $(n=7)$, then the percentage of aneuploid (between 8 and 13 chromosomes) and diploid $(2 n=14)$ mitotic figures increased. Aneuploid mitoses reached a plateau of about $40 \%$ after $14 \mathrm{~h}$; this coincided with the fall in plating efficiency (Fig. 2a). Aneuploid nuclei frequently occurred as pairs within the same cytoplasm. Examples of these are shown in Fig. 4(a) $(6+8$ chromosomes), Fig. 4(b) $(9+5$ chromosomes) and Fig. 4(c) $(10+4$ chromosomes). Aneuploids were rarely seen in control or ben late-treated cultures. No aneuploid strains were isolated when cultures containing aneuploid mitotic nuclei were plated on SM agar.

\section{Effects of benzimidazole derivatives on bacterially grown cells}

The concentrations of thiabendazole and cambendazole used in experiments with cells growing in axenic medium had similar effects on cells growing on bacteria. The mitotic index of bacterially grown cells treated with thiabendazole was greater than $30 \%$ by $3 \mathrm{~h}$ and then decreased (Fig. 5). This result is consistent with the result for cells growing in axenic medium considering the shorter generation time of bacterially grown cells $(3.5 \mathrm{~h}$ as compared to $10 \mathrm{~h}$ ). Cell division was again inhibited, although approximately one round of cell division occurred by $12 \mathrm{~h}$ (Fig. 6). After $24 \mathrm{~h}$ the cell number gradually decreased (results not shown). Cells treated with either thiabendazole or cambendazole varied greatly in size from at least twice the diameter of untreated cells to very small dark cells. A decrease in plating efficiency and an induction of isogenic diploids similar to those seen with axenically grown cells were also observed with bacterially grown cells treated with thiabendazole (Fig. $7 a$ ) or cambendazole (Fig. $7 b$ ). The formation of isogenic diploids coincided with the decrease in plating efficiency. The proportion of diploids reached a peak of greater than $50 \%$ at $12 \mathrm{~h}$ for cells treated with thiabendazole and then declined to $25 \%$ by $24 \mathrm{~h}$ (Fig. $7 a)$. For cambendazole-treated cells, the percentage of diploids reached a maximum between 12 and $24 \mathrm{~h}$ (Fig. $7 \mathrm{~b}$ ); by $48 \mathrm{~h}$ the percentage of diploids had fallen to $25 \%$. Control cultures remained haploid throughout and had plating efficiencies above $80 \%$.

Nocodazole at $7 \mu \mathrm{g} \mathrm{ml}^{-1}$ had no effect on the doubling time of cells growing on bacteria (Fig. 6). The mitotic index increased to only $9 \%$ by $2 \mathrm{~h}$ and then decreased (Fig. 5). No isogenic diploids were recovered from bacterially grown cells treated with nocodazole nor was there any apparent effect on plating efficiency, which at all times was greater than $80 \%$.

Ben late at $100 \mu \mathrm{g} \mathrm{ml}^{-1}$ increased the doubling time of cells growing on live bacteria to $5 \mathrm{~h}$ (Fig. 6 ) and decreased the plating efficiency to about $40 \%$ by $24 \mathrm{~h}$. Diploids were rarely recovered, if at all, from ben late-treated cells grown on live bacteria. 


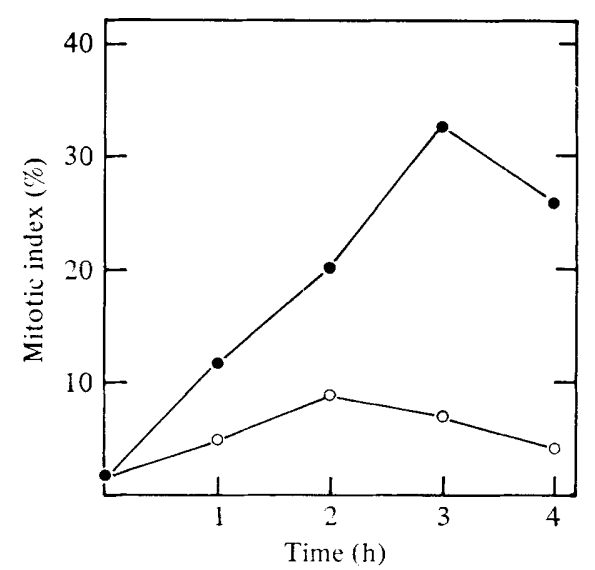

Fig. 5

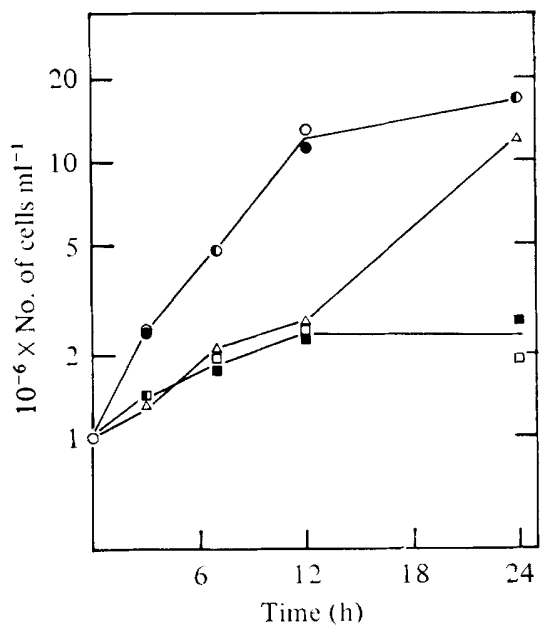

Fig.' 6

Fig. 5. The mitotic index of bacterially grown amoebae of strain $\mathrm{AX} 3$ treated with $10 \mu \mathrm{g}$ thiabendazole $\mathrm{ml}^{-1}(0)$ or $7 \mu \mathrm{g}$ nocodazole $\mathrm{ml}^{-1}(O)$.

Fig. 6. Growth of amoebae of strain AX3 on Escherichia coli $\mathrm{B} / \mathrm{r}$ with no inhibitor $(O), 7 \mu \mathrm{g}$ nocodazole $\mathrm{ml}^{-1}(\bullet), 10 \mu \mathrm{g}$ thiabendazole $\mathrm{ml}^{-1}(\square), 50 \mu \mathrm{g}$ cambendazole $\mathrm{ml}^{-1}(\mathbf{E})$ or $100 \mu \mathrm{g}$ ben late $\mathrm{ml}^{-1}(\triangle)$.

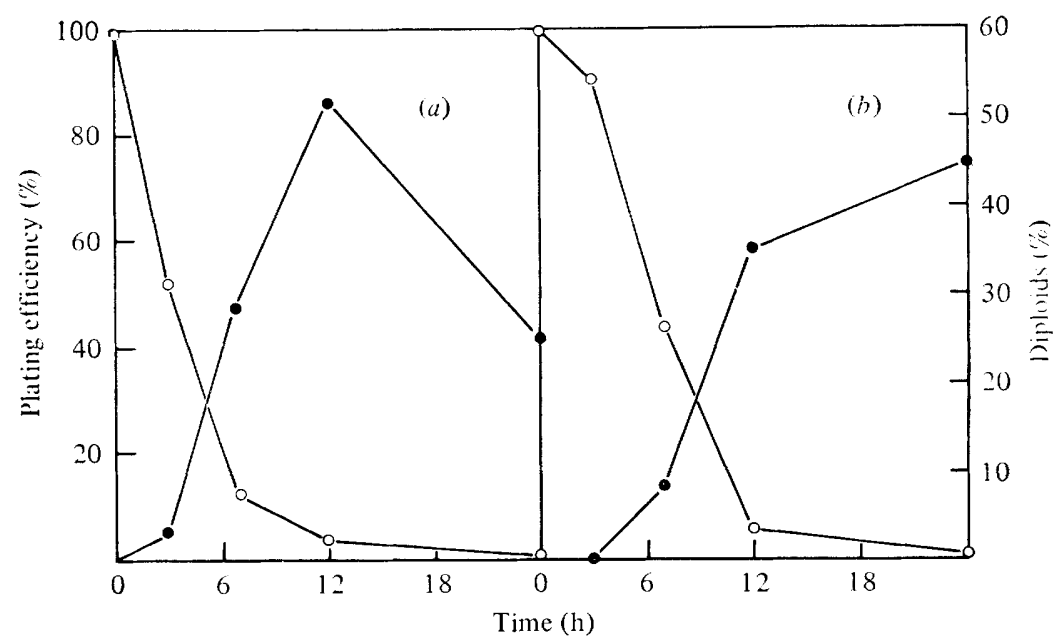

Fig. 7. The percentage of diploid colonies $(\bullet)$ and plating efficiency $(O)$ of bacterially grown amoebae of strain AX3 treated with $10 \mu \mathrm{g}$ thiabendazole $\mathrm{ml}^{-1}(a)$ or $50 \mu \mathrm{g}$ cambendazole $\mathrm{ml}^{-1}(b)$.

\section{Effect of ben late on cells grown on autoclaved bacteria}

After much trial and error, conditions were found under which ben late induced a high frequency of isogenic diploids. These were prolonged incubation following growth on autoclaved bacteria in the presence of ben late at $100 \mu \mathrm{g} \mathrm{ml}^{-1}$ with yeast extract and bacteriological peptone. Under these conditions the percentage of isogenic diploids rose to $27 \%$ by $96 \mathrm{~h}$. Without the addition of yeast extract and peptone the proportion of diploids induced by ben late at $100 \mu \mathrm{g} \mathrm{ml}^{-1}$ was only $5 \%$ at $96 \mathrm{~h}$ (Fig. 8). Cell doubling times on autoclaved bacteria were about $6 \mathrm{~h}$ for both control and ben late-treated amoebae with or without the addition of yeast extract and peptone. By $48 \mathrm{~h}$, the control and ben latetreated cells reached stationary phase at greater than $10^{7}$ cells $\mathrm{ml}^{-1}$ from initial concentrations of $4.5 \times 10^{5}$ cells $\mathrm{ml}^{-1}$. The plating efficiency of the ben late-treated cells both with and 


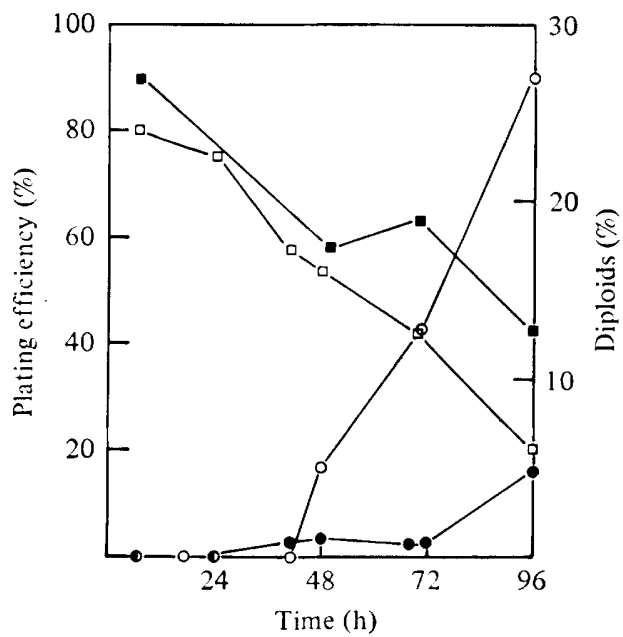

Fig. 8. The percentage of diploid colonies $(O, \odot)$ and plating efficiency $(\square, \square)$ of amoebae of strain AX3 after growth on autoclaved bacteria in the presence $(O, \square)$ or absence $(\odot, \square)$ of yeast extract and bacteriological peptone.

Table 2. Plating efficiency and haploidization of diploid strain DU319 on SM agar containing low concentrations of thiabendazole, cambendazole, nocodazole or ben late

\begin{tabular}{|c|c|c|c|}
\hline $\begin{array}{l}\text { Haploidizing } \\
\text { agent* }\end{array}$ & $\begin{array}{c}\text { Final } \\
\text { concn in } \\
\text { SM agar } \\
\left(\mu \mathrm{g} \mathrm{ml}^{-1}\right)\end{array}$ & $\begin{array}{c}\text { Plating } \\
\text { efficiency } \dagger \\
(\%)\end{array}$ & $\begin{array}{c}\text { Haploids } \\
(\%)\end{array}$ \\
\hline Thiabendazole & 2 & 15 & 100 \\
\hline Cambendazole & 10 & 49 & 92 \\
\hline Nocodazole & 5 & 47 & 100 \\
\hline Ben late & 20 & 14 & 93 \\
\hline
\end{tabular}

* These compounds were added to molten SM agar after autoclaving as a powder (ben late) or dissolved in DMSO (thiabendazole, $10 \mathrm{mg} \mathrm{ml}^{-1}$; cambendazole, $50 \mathrm{mg} \mathrm{ml}^{-1}$; nocodazole, $5 \mathrm{mg} \mathrm{ml}^{-1}$ ).

+ Plating efficiency as a percentage of that on SM agar. Diploid DU319 has a plating efficiency of about $70 \%$ on SM agar.

without yeast extract and peptone decreased to about $40 \%$ at $96 \mathrm{~h}$ (Fig. 8) but remained above $70 \%$ for control cells (data not shown).

\section{Haploidization of pre-existing diploids}

Ben late has previously been shown to be an effective haploidizing agent for $D$. discoideum (Williams \& Barrand, 1978). At $20 \mu \mathrm{g} \mathrm{ml}^{-1}$ ben late induced between 90 and $100 \%$ haploidization of the diploid DU319 while decreasing the plating efficiency to about $20 \%$. Thiabendazole $\left(2 \mu \mathrm{g} \mathrm{ml}^{-1}\right)$, cambendazole $\left(10 \mu \mathrm{g} \mathrm{ml}^{-1}\right)$ or nocodazole $\left(5 \mu \mathrm{g} \mathrm{ml}^{-1}\right)$ also induced between 90 and $100 \%$ haploidization of DU319 while lowering the plating efficiency to between 15 and $50 \%$ (Table 2). Lower concentrations of thiabendazole $\left(1 \mu \mathrm{g} \mathrm{ml}^{-1}\right)$, cambendazole $\left(5 \mu \mathrm{g} \mathrm{ml}^{-1}\right)$ or nocodazole $\left(2 \mu \mathrm{g} \mathrm{ml}^{-1}\right)$ were not as effective at inducing haploidization and did not affect plating efficiency. Higher concentrations of thiabendazole $\left(5 \mu \mathrm{g} \mathrm{ml}^{-1}\right)$ or cambendazole $\left(20 \mu \mathrm{g} \mathrm{ml}^{-1}\right)$ also induced haploidization but decreased the plating efficiency further. 


\section{DISCUSSION}

The benzimidazole derivatives used in this study were found to have five effects on D. discoideum: (i) the induction of mitotic arrest; (ii) the induction of isogenic diploids through chromosome doubling; (iii) the haploidization of pre-existing diploids; (iv) the lowering of plating efficiency; and (v) the inhibition of cell division. The first four effects can be directly attributed to a disruption of the mitotic spindle which would, in turn, affect the separation of chromosomes and lead to the induction of polyploids and aneuploids through non-disjunction. The decrease in plating efficiency is most likely due to the increase in aneuploidy observed in these experiments, and not to a 'deterioration of chromosomal structure' (Cappuccinelli et al., 1979); cultures with high frequencies of aneuploids have previously been observed to have low plating efficiencies due presumably to low viability of aneuploid cells. No aneuploid strains have been reported (Brody \& Williams, 1974). Antimitotic effects of MBC have been found previously (Davidse, 1973; Hammerschlag \& Sisler, 1973; Styles \& Garner, 1974; Seiler, 1975, 1976; Zutshi \& Kaul, 1975). The antitumour drug, nocodazole, has recently been shown to induce mitotic arrest of cultured mammalian cells (DeBrabander et al., 1975) and of cells of D. discoideum (Cappuccinelli et al., 1979). To our knowledge, thiabendazole and cambendazole have not been used previously to induce mitotic arrest.

Present evidence indicates that the major genetic effect of benomyl and thiabendazole on Aspergillus nidulans is the induction of non-disjunction (Hastie, 1970; Kappas et al., 1974; Kappas, 1978). While benomyl and $\mathrm{MBC}$ have been reported to induce point mutations in Salmonella typhimurium (Seiler, 1972; Kappas et al., 1976), the induction of point mutations was not observed in A. nidulans (Hastie, 1970; Kappas et al., 1974; Kappas, 1978), Saccharomyces cerevisiae (Siebert et al., 1970) or mammalian cells (Seiler, 1975). Likewise, we have not detected changes in the frequency of developmental mutants in $D$. discoideum following treatment with any of the benzimidazole derivatives; their major genetic effect on $D$. discoideum appears to be the induction of non-disjunction.

The studies we report here using benzimidazole derivatives show that the increase in mitotic index is transitory and that the final block of cell division is in interphase. However, we disagree with the claim of Cappuccinelli et al. (1979), who only used nocodazole, that rapid deterioration of chromosomal structure occurred as the mitotic index decreased. Chromosomes and nuclei observed after the initial period of mitotic arrest appeared normal throughout these experiments although the nuclei varied in size. Our results suggest that benomyl (or MBC) has less effect than the other benzimidazole derivatives on spindle microtubules. While ben late did not block the cells in mitosis, it did induce haploidization of pre-existing diploids, inhibit cell division and induce a low frequency of chromosome doubling. The interference with cell division is reversible, particularly for ben late-treated cells, since the plating efficiency remained high. The low plating efficiency of cells treated with the other inhibitors is most likely due to the increase in aneuploidy and not to irreversible effects on microtubules.

In other systems, the primary effect of these benzimidazole derivatives appears to be on tubulin; several reports have described their binding to tubulin derived from both rat and bovine brain and also to fungal tubulin from A. nidulans (Hoebeke et al., 1976; DeBrabander et al., 1976; Friedman \& Platzer, 1978; Davidse, 1975; Davidse \& Flach, 1977). The toxicity of these compounds varies from species to species. For instance, the most effective inhibitor of the polymerization of bovine brain tubulin in vitro was nocodazole and the least effective was thiabendazole, yet both had similar effects on axenically grown $D$. discoideum. Likewise, the order of effectiveness of these benzimidazole derivatives for growth inhibition of the nematode Caenorhabditis elegans differed from that found for inhibition of the polymerization of bovine tubulin (Platzer et al., 1977). The effectiveness of the benzimidazole derivatives on the induction of mitotic arrest also differs amongst species of cellular slime moulds. 
While having little effect on mitotic arrest of $D$. discoideum, ben late induced a mitotic index of greater than $60 \%$ in Polysphondylium pallidum (Williams, 1980). However, even with $D$. discoideum we have found differences in the toxicity of ben late and nocodazole with amoebae grown in different ways. The effectiveness of these compounds presumably varied due to bacterial degradation or differences in the physiological state of the cells. The induction of isogenic diploids was dependent on the addition of yeast extract and bacteriological peptone in the ben late experiments using autoclaved bacteria, where bacterial degradation is excluded.

The benzimidazole derivatives provide three important advances in slime mould genetic analysis: haploidization, chromosome doubling and metaphase arrest. The duration of treatment and concentrations of benzimidazole derivatives used are critical. Diploid strains haploidize upon prolonged exposure to concentrations of the benzimidazole derivatives which do not prevent cell division of haploid strains. On the other hand, for successful metaphase arrest and chromosome doubling, the benzimidazole derivatives must be used for short periods at concentrations which prevent cell division. All four benzimidazole derivatives used were effective in the induction of haploidization of pre-existing diploids, an important step of the parasexual cycle. The procedures reported here make isolation of isogenic diploids routine. Although isogenic diploid strains of $D$. discoideum have been reported previously (Ross, 1960; Sussman, 1964; Wilson, 1953; Wilson \& Ross, 1957), attempts to obtain isogenic diploids through controlled experiments have been unsuccessful in the past (Ross, 1960) except Sussman's (1964) report of success using unaggregated amoebae. We have isolated isogenic diploids from a number of axenic and non-axenic strains using thiabendazole at $10 \mu \mathrm{g} \mathrm{ml}^{\mathbf{1}}$. Such diploids will be of value, for instance, in studies determining the effect of ploidy on mutation (Williams, 1976) and on cell patterning during the developmental cycle (Stenhouse \& Williams, unpublished results). Mitotic arrest in excess of $30 \%$ is now routine in axenic culture (Cappuccinelli et al., 1979; this report). Since nocodazole is relatively ineffective in the presence of live bacteria, its usefulness is diminished since many strains are unable to grow axenically. However, thiabendazole and cambendazole are equally effective on axenically and bacterially grown amoebae. Amoebae taken directly from clonal plates and treated for $2.5 \mathrm{~h}$ with thiabendazole at $10 \mu \mathrm{g} \mathrm{ml}^{-1}$ routinely gave mitotic indices in excess of $30 \%$, which provides enough mitoses for rapid karyotypic analysis. This procedure was effective on both haploid and diploid strains derived from $\mathrm{NC} 4$ and also on a number of other wild isolates of $D$. discoideum (Robson \& Williams, 1980).

The high cost of colchicine and nocodazole precludes their routine use in solid media etc. By contrast, thiabendazole, cambendazole and ben late are all used commercially as fungicides or anthelminthics, so they are obtainable in large quantity for little cost. This report has been concerned primarily with the application of benzimidazole derivatives to genetic analysis in $D$. discoideum. However, they may prove valuable in studies involving microubules other than those of the mitotic spindle. It is apparent that microtubules may have important roles in developmental processes such as cell wall formation in plants and algae (Dustin, 1978) and morphogenetic processes in D. discoideum (O'Day \& Durston, 1978).

During the course of this investigation, D.L.W. was initially supported by grant DRG206-F of the Damon Runyon-Walter Winchell Cancer Fund and subsequently by a National Institutes of Health Fellowship (1 F32 CA06162-01) from the National Cancer Institute. We thank William Bliss for the gift of thiabendazole and cambendazole. We thank Professor B. Gunning, Drs H. Marchant, E. Smith and K. Sriprakash for their comments on this manuscript. 


\section{REFERENCES}

Brody, T. \& Williams, K. L. (1974). Cytological analysis of the parasexual cycle in Dictyostelium discoideum. Journal of General Microbiology 82, 371-383.

Cappuccinelli, P., Fighetti, M. \& Rubino, S. (1979). A mitotic inhibitor for chromosomal studies in slime moulds. FEMS Microbiology Letters 5, 25-27.

Clemons, G. P. \& Sisler, H. D. (1969). Formation of a fungitoxic derivative from ben late. Phytopathology 59, 705-706.

DAvidse, L. C. (1973). Antimitotic activity of methyl benzimidazol-2-yl carbamate (MBC) in Aspergillus nidulans. Pesticide Biochemistry and Physiology 3, 317-325.

Davidse, L. C. (1975). Antimitotic activity of methyl benzimidazol-2-yl carbamate in fungi and its binding to cellular protein. In Microtubules and Microtubule Inhibitors, pp. 483-495. Edited by M. Borgers \& M. DeBrabander. Amsterdam: North-Holland Publishing Co.

Davidse, L. C. \& Flach, W. (1977). Differential binding of methyl benzimidazol-2-yl carbamate to fungal tubulin as a mechanism of resistance to this antimitotic agent in mutant strains of Aspergillus nidulans. Journal of Cell Biology $\mathbf{7 2}$, 174-193.

DeBrabander, M., Van de Veire, R., Aerts, F., Geuens, G., Borgers, M., Desplenter, L. \& DeCree, J. (1975). Oncodazole (R 17934): a new anti-cancer drug interfering with microtubules. Effects on neoplastic cells in vitro and in vivo. In Microtubules and Microtubule Inhibitors, pp. 509521. Edited by M. Borgers \& M. DeBrabander. Amsterdam: North-Holland Publishing Co.

DeBrabander, M., Van de Veire, R., Aerts, F., Borgers, M. \& JANSSEN, P. A. J. (1976). The effects of methyl [5-(2-thienylcarbonyl)-1H-benzimidazol-2-yl] carbamate, (R 17934; NSC 238159), a new synthetic antitumoral drug interfering with microtubules, on mammalian cells cultured in vitro. Cancer Research 36, 905-910.

Deering, R. A., Smith, M. S., Thompson, B. K. \& Adolf, A. C. (1970). Gamma-ray-resistant and -sensitive strains of slime mould (Dictyostelium discoideum). Radiation Research 43, 711-728.

Dustin, P. (1978). Microtubules. Berlin: SpringerVerlag.

Friedman, P. A. \& Platzer, E. G. (1978). Interaction of anthelminthic benzimidazoles and benzimidazole derivatives with bovine brain tubulin. Biochimica et biophysica acta 544, 605-614.

Galeotti, C. L. \& Williams, K. L. (1978). Giemsa staining of mitotic chromosomes in Kluyveromyces lactis and Saccharomyces cerevisiae. Journal of General Microbiology 104, 337-341.

HammerschlaG, R. S. \& Sisler, H. D. (1973). Benomyl and methyl-2-benzimidazolecarbamate (MBC): biochemical, cytological and chemical aspects of toxicology to Ustilago maydis and Saccharomyces cerevisiae. Pesticide Biochemistry and Physiology 3, 42-54.

Hastie, A. C. (1970). Ben late-induced instability of Aspergillus diploids. Nature, London 226, 771.
Hoebeke, J., Van Nijen, G. \& DeBrabander, M. (1976). Interaction of oncodazole (R17934), a new antitumoral drug, with rat brain tubulin. Biochemical and Biophysical Research Communications 69, 319-324.

KAPPAS, A. (1978). On the mechanism of induced somatic recombination by certain fungicides in Aspergillus nidulans. Mutation Research 51, 189197.

Kappas, A., Georgopoulos, S. G. \& Hastie, A. C. (1974). On the genetic activity of benzimidazole and thiophanate fungicides on diploid Aspergillus nidulans. Mutation Research 26, 17-27.

Kappas, A., Green, M. H. L., Bridges, B. A., Rogers, A. M. \& Muriel, W. J. (1976). Benomyla novel type of base analogue mutagen? Mutation Research 40, 379-382.

LoOмIs, W. F. (1971). Sensitivity of Dictyostelium discoideum to nucleic acid analogues. Experimental Cell Research 64, 484-486.

O'Day, D. H. \& Durston, A. J. (1978). Colchicine induces multiple axis formation and stalk cell differentiation in Dictyostelium discoideum. Journal of Embryology and Experimental Morphology 47, 195-206.

Platzer, E. G., Eby, J. E. \& Friedman, P. A. (1977). Growth inhibition of Caenorhabditis elegans with benzimidazoles. Journal of Nematology 9, 280.

Robson, G. E. \& Williams, K. L. (1977). The mitotic chromosomes of the cellular slime mould Dictyostelium discoideum: a karyotype based on Giemsa banding. Journal of General Microbiology 99, 191-200.

Robson, G. E. \& Williams, K. L. (1980). The mating system of the cellular slime mould Dictyo. stelium discoideum. Current Genetics (in the Press).

Ross, I. K. (1960). Studies on diploid strains of Dictyostelium discoideum. American Journal of Botany 47, 54-59.

SEILER, J. P. (1972). The mutagenicity of benzimidazole and benzimidazole derivatives. I. Forward and reverse mutations in Salmonella typhimurium caused by benzimidazole and some of its derivatives. Mutation Research 15, 273-276.

SeILER, J. P. (1975). Toxicology and genetic effects of benzimidazole compounds. Mutation Research 32, 151-168.

SeILER, J. P. (1976). The mutagenicity of benzimidazole and benzimidazole derivatives. VI. Cytogenetic effects of benzimidazole derivatives in the bone marrow of the mouse and the Chinese hamster. Mutation Research 40, 339-348.

Siebert, D., ZimmermanN, F. K. \& Lemperle, E. (1970). Genetic effects of fungicides. Mutation Research 10, 533-543.

Styles, J. A. \& GARner, R. (1974). Benzimidazole carbamate methyl ester - evaluation of its effects in vivo and in vitro. Mutation Research 26, 177187.

SuSSMAN, M. (1964). Isolation of diploid strains of Dictyostelium discoideum from haploid populations. Nature, London 201, 216. 
Sussman, M. (1966). Biochemical and genetic methods in the study of cellular slime mold development. Methods in Cell Physiology 2, 397-410.

Sussman, R. R. (1961). A method for staining the chromosomes of Dictyostelium discoideum myxamoebae in the vegetative stage. Experimental Cell Research 24, 154-155.

Watts, D. J. \& Ashworth, J. M. (1970). Growth of myxamoebae of the cellular slime mould Dictyostelium discoideum in axenic culture. Biochemical Journal 119, 171-174.

Williams, K. L. (1976). Mutation frequency at a recessive locus in haploid and diploid strains of slime mould. Nature, London 260, 785-786.

Williams, K. L. (1980). Examination of the chromosomes of Polysphondylium pallidum following metaphase arrest by benzimidazole derivatives and colchicine. Journal of General Microbiology 116, 409-415.

Williams, K. L. \& BarRand, P. (1978). Parasexual genetics in the cellular slime mould Dictyostelium discoideum: haploidisation of diploid strains using ben late. FEMS Microbiology Letters 4, 155-159.

Williams, K. L. \& Newell, P. C. (1976). A genetic study of aggregation in the cellular slime mould Dictyostelium discoideum using complementation analysis. Genetics 82, 287-307.

Wilson, C. M. (1953). Cytological study of the life cycle of Dictyostelium. American Journal of Botany 40, 714-718.

Wilson, C. M. \& Ross, I. K. (1957). Further cytological studies in the Acrasiales. American Journal of Botany 44, 345-350.

ZADA-HAMES, I. M. (1977). Analysis of karyotype and ploidy of Dictyostelium discoideum using colchicine-induced metaphase arrest. Journal of General Microbiology 99, 201-208.

ZuTShI, U. \& Kaul, B. L. (1975). Studies on the cytogenetic activity of some common fungicides in higher plants. Cytobios 12, 61-67. 